QIJIS : Qudus International Journal of Islamic Studies

Volume 7, Number 1, 2019

DOI : $10.21043 /$ qijis.v7i1.4809

\title{
ISLAM SUPPORTS DEMOCRACY:THE VIEWS OF PARTAI ISLAM SE-MALAYSIA (PAS) AND THEIR IMPLEMENTATION IN THE RECRUITMENT OF THE PARTY'S MEMBERS AND LEADERS
}

\author{
Ahmad Ali Nurdin \\ UIN Sunan Gunung Djati Bandung \\ nurdinster@gmail.com
}

\begin{abstract}
:
This paper discusses the views of Partai Islam Se-Malaysia (PAS) on democracy and their implementation in real politics in Malaysian context. It analyzes PAS' views on the relationship between Islam and democracy, as well as the party's style in recruiting members and leaders to demonstrate that this Islamic political party follows democratic rules. PAS believes that democracy and Islamic values are compatible and it is a good political instrument for an Islamic party like PAS to reach its political goals. Examining the recruitment process of members and leaders of PAS, the paper shows that the commitment of PAS in toning up democracy in Malaysia is reflected by the party's style in recruiting leaders. PAS has exercised democratic rules in its internal party activities, particularly in the recruitment of members and selection of leaders.
\end{abstract}

Keywords: PAS; Islamic Party; Democracy; Malaysia 


\section{A. Introduction}

This paper examines the views of Partai Islam Se-Malaysia (PAS) on democracy and the party's efforts to implement democratic rules. In the processes of recruiting members and selecting leaders, PAS has implemented the concept of shura to demonstrate that it can reconcile between Islamic values and democracy. To determine the extent to which PAS practices democratic principles, it is important to scrutinize whether or not PAS has restricted their members to be nominated as leadership candidates of the party. Does PAS give an equal opportunity to all members to be selected and become the party's leader or president? How does PAS recruit its members? By answering these questions, PAS' commitment to the principles of democracy can be disclosed.

Partai Islam Se-Malaysia (PAS) was officially established on 24 November 1951, as a consequence of the internal breakup of the United Malays National Organization (UMNO). PAS was initially a branch of UMNO which was established in 1946 by the Malay nationalist movement and was intended to unite the Malays-Muslims of the country in anticipation of independence (Kassim, 2017, p. 2)The history of PAS could not be separated from the history of ulama (religious scholars) in Malaysia. Due to the significant role of ulamaamong Malay Muslim citizens living in the Malaysian suburban society, UMNO tried to accommodate them in the party. Thus, on May 11, and 12,1946, UMNO ratified its charter which stated, among other things, that one of the departments in the party was the Department of Religious Affairs and Education (Ibrahim, 1981, pp. 10-11).

However, UMNO's effort to establish Religious Affairs Department in its internal structure seemed to be paving the way for ulama to form their own organization, later known as PAS. This new Religious Affairs department as part of UMNO's structure evidently resolved to sponsor ulama conferences to deal with religious matters, which were usually handled by the UMNO Executive Committee (Nor, 2004, p. 8). 
The ulama conference had been held three times prior to the establishment of PAS. The first conference was held on February 21-22, 1950 which decided several resolutions on religious matters. One of the resolutions was to form a liaison religious council with the objective of facilitating consultations on religious affairs among the Muslims so that the running of the religious affairs could be unified. It was followed by the second conference held on August 23, 1950 at Sultan Sulaiman Club, Kuala Lumpur. Hasyim pointed out that three important decisions were made in this conference:

1) to establish an independent ulama organization; 2) to introduce a temporary committee to establish an organization; 3) to continue fighting for the establishment of a religious organization as part of the Federation of Malaya (Hasyim, 1993, p. 23).

The resolutions of the second conference of ulama showed that not only did they form an ulama union, named Persatuan Ulama-ulama Se Malaya, PUSM (Malay Union of Islamic Religious Scholars), there was also an aspiration among ulama to form an Islamic party. Thus, it is not surprising that in the third ulama conference held at Butterworth on November 24, 1951, the ulama decided to form what is now known as Parti Islam Se-Malaysia (PAS)(Ibrahim, 1981, p. 23).

\section{B. PAS' views on democracy}

The PAS' view that democracy is the best way to articulate its political aspirations has been confirmed since its third annual conference held on January 4, 1953 (Zain, 2014, pp. 37-45). One of the conference recommendations was to work hard at disseminating and promoting the concept of democracy and its advantages to Muslim people, particularly in Malaysia. This recommendation was also reconfirmed at the PAS third general meeting held in Madrasah al-Tahdib al-Diniyah, Parit Buntar, Perak, on August 1214,1954 , in which PAS decided to participate in the 1955 Malaysian General Election (Muhammad, 1994, p. 45). Up to 2018, PAS has 
consistently participated in Malaysian election to show that the party accepted democratic rules (Saat, 2018, pp. 1-9). However, PAS did not perform well in the last 2018 election (Moniruzzaman, M. and Farzana, 2018, pp. 217-228).

The 1955 general election was the first political test for the PAS to be involved in the democratization process in Malaysian politics (Nor, Riduan Mohd and Ahmad, 2013, p. 11). Although PAS only won one parliament seat in this first election, this did not discourage PAS to continue its struggle through acceptance of democratic rules. Dr. Burhanuddin Al-Helmi as in (Adam, 2000, p. 158) stated that his party will always struggle through democratic rules to achieve its goals. PAS still believes that democracy is the best way to achieve its political goals (Case, William F. and Tong, 2006, pp. 385-406). Thus, PAS does not agree with Islamic groups which use radicalism and violence as tools to achieve their objectives. One of the parliament members from PAS, Mohamad Sabu, as cited in Zain, expressed:

Our struggles have been moving up and down, but we still hold up democracy. Although several Islamic movements in the world criticized our struggle by saying that Islamic movement will not succeed through democracy, we always believe that through democracy we will achieve our goals. Through people's voices, we will get our victory as long as the democratic rules are accordingly implemented, particularly by the ruling government. Although other Islamic groups criticized us, we say to them that we will always follow the democratic path to achieve our objectives (Zain, 2005, p. 61).

From Sabu's statement above, it is clear that PAS not only believes that democracy is the best way to voice aspirations, but also reminds the ruling party to always maintain and follow democratic rules. The 'room' for democracy should be open to all people and civil society movements in Malaysia including the opposition parties (Farouk, 2011, pp. 91-109). PAS' dedication to democracy is then unquestionable. 
The commitment of the party to democracy of course is not without reasons. Several leading figures of PAS believe that in the era of nation state and global politics in the world, one could not neglect the concept of democracy which was popularized by Western countries (Loh, 2012, p. 21). Based on the political situation in Malaysia, PAS believes that there is no other way to be involved in the political arena except to follow democratic rules. The statute of the party, article 6 (5) says that the party's efforts to be involved in democratic struggle are "to provide plans and actions as well as to improve societal institutions, political forms, economic justice and state prosperity; and to defend Muslim's interests and Malaysian people as a whole" (Pejabat Agung PAS Pusat, 2002, p. 3).

The comments of leading figures of PAS on democracy strengthen the argument that PAS, up to the present, still upholds a belief in democracy to achieve its objectives. PAS also believes that democracy (election) could be seen as a political mechanism to gain its objectives to pursue Islamic law in Malaysia if it gets major support from the people. As Weiss argues, parties in Malaysia, including PAS, got through profoundly into the heart of Malaysian people (Weiss, 2013, pp. 19-37). Democracy will give an opportunity to both Muslim and non-Muslim voters in Malaysia to decide whether to vote for PAS or not. If the Malaysian people agree with the political agenda of PAS, they can freely choose the party, or vice versa. This means that there is no compulsion for the people to choose whatever parties' objective they prefer in the election. The freedom of to choose is the core of democracy (Adam, 2000, pp. 265-279).

The late Nik Abdul Aziz Nik Mat, the former Mursyidul Am PAS and "one of the most well-known political-religious leaders in Malaysia" (Noor, 2015, pp. 1-2) argued that democratic procedures could be used by PAS as an opposition party and UMNO as a ruling party to discuss and debate (mudzakarah) political issues and problems among them. At the parliament meetings, both at the 
local and national levels, for example, all parliament members (from PAS and UMNO) can meet and discuss any political issues that Malaysians face. These mutual discussions between the ruling party and opposition party in the parliament are in line with the teaching of Islam, which encourages people to have musyawarah (discussion) to solve any problems (Zain, 2005, p. 63).

Although Nik Aziz seemed to agree with the concept of democracy, at the same time he criticized it because sometimes democracy could lead to political conflicts among the people (Haron, 2005 , p. 30). He pointed out, for example, the general election, which is held every five years in Malaysia. Prior to the general election, Malaysians are usually divided into several groups due to their different political alliances, which could lead to conflicts among the parties' supporters. Moreover, Islam has differentiated between good and bad deeds in which Muslims could not choose both of them but always followed the good ones. In democracy, instead, people could select even the bad thing as long as the majority of the people want to do so. This is another negative side of democracy.

PAS' criticisms of democracy, however, did not deflect it from the process of democratization and its involvement in the democratic process like the election. Abdul Hadi Awang, the president of PAS, insists that PAS will always continue to follow the rule of democracy, participate in a general election and oblige its members to vote when the general election is held (Awang, 2007a, pp. 20-24). He furthermore argues that whoever rejects the party's policy to participate in the election has to leave the party.

PAS' involvement in democratization in Malaysia is not without criticism from its opponents like UMNO. PAS was commonly attacked by its competitors as a party which is not genuinely supporting democracy. PAS has been criticized as using democracy to gain political power and that once it holds power, it would destroy democratic institutions in Malaysia. This criticism, actually, was not only directed to PAS, but also to other Islamic movements 
in the world. Islamic movements are commonly portrayed as antidemocracy, anti-secularism and authoritarian; they are seen as using democracy to gain their objectives.

PAS' commitment to democracy can also be seen further from the statement of PAS president Abdul Hadi Awang in his opening speech at the $53^{\text {rd }}$ Muktamar (annual meeting) in Kelantan entitled Selamatkan Demokrasi, Tegakkan Keadilan." Awangsays,

PAS always chooses a fair competition through democracy. The democratic way would be PAS' way to achieve the party's objectives to achieve justice and prosperity for all people (Awang, 2007b, pp. 1-2).

According to the party's statute, article 5 (1-2), PAS' objectives are to "struggle for creating society and government who implement Islamic values and laws under Allah's blessings; and to protect the holiness of Islam as well as freedom and sovereignty of the state" (Pejabat Agung PAS Pusat, 2002, p. 2). Thus, it is clear that up to the present, PAS has institutionally accepted the concept of democracy and still follows democratic rules to achieve its political objectives which can also be seen from the fact that the party keeps participating in the Malaysian elections since PAS' establishment in 1951.

From the previous discussions, it is clear that PAS agrees that Islamic values are not inimical to democracy. The party believes that the core values of democracy are also recognized in Islamic teaching. Nik Aziz, a former spiritual leader of PAS argued that Islam and democracy are not in contradiction because democracy could be considered as a system that admits the muwajahah silmiyah (smooth and soft way) to gain political power as promoted by Islamic teaching. Thus, PAS has a view in embracing democratic ways to achieve its political goals. The party does not agree with Islamic groups that use radicalism and violence as the principle tools to achieve their objectives; the participation of PAS in the national elections reflects their commitment to abide by democratic rules. 


\section{PAS membership}

As a party influenced by Islamic parties in the Middle Eastern countries, does PAS use a method similar to that of its counterparts in the Middle East? If not, how does PAS modify the recruitment of members to adapt to the Malaysian political context?

Farish A. Noor, a Malaysian political scientist, argued that although the establishment of PAS was much influenced by Islamic movements in the Middle Eastern countries like al-ikhwan al-muslimun (Egypt) and Jamaat al-Islami (Pakistan), PAS has a different style from its predecessors in terms of membership recruitment and its approaches to constituents and members. While some Islamist movements like Jamaat al-Islami preferred a topdown approach and others practiced the bottom-up approach to build their solid political base, PAS has always tried to combine both approaches. Noor explained that "being a political party born and bred in the climes of traditional Malay neo-feudal politics, PAS has exploited both established notions and values of leadership as well as modern modes of recruitment, mobilization and indoctrination" (Noor, 2002, pp.5-6). In my direct observation in Kota Bharu in 1-7 August 2017, Kelantan, I found that Noor's argument above is correct. The party keeps maintaining its potential assets like Ulama as party generators to attract members while at the same time adapting to a modern situation in which madrasah (Islamic schools) and campuses are used by PAS as places to recruit members. PAS currently is not only maximizing its ulama's role in recruitment of members (ahli) through pengajian (Islamic teaching gathering), which is routinely held around Kelantan both in mosques and open fields, but also intensifying recruitment by using the internet as a medium to promote the party to the public. What is missing from Noor's findings, however, is that the party's activists, particularly the young members represented by the Dewan Pemuda PAS, used modern educational institutions, like PASTI, and also the internet as tools to recruit members. 
In its manner of recruiting members and sympathizers in the early days of its establishment, PAS tried to maximize the ulamas' role as leading figures and potential party assets in recruiting members and promoting their ideas and programs as an Islamic political party. During the 1950s and 1970s, PAS leading figures such as Dr. Burhanuddin and Asri Muda promoted PAS' influence through face-to-face meetings and communication with village grassroots people. Different from the style of the Jamaat alIslami which seemed to be elitist in recruiting its members, PAS tried to send its political message directly to people on the streets and in villages. Thus, one favorite meeting venue for PAS leaders during the early period of its establishment would be the coffee shop. They preferred to directly listen to what grassroots people wanted PAS to do in its political activities. This approach was likely to have been effective in attracting Malay Muslims in the villages to be sympathetic to the new Islamic party, PAS.

In the 1980s, when the PAS had become familiar to Malaysians, the party tried to expand its recruitment. Although the leading figures still kept up their face-to-face approach, during this era PAS also concentrated its efforts on recruiting members from madrasahs, Islamic boarding schools (pesantren), mosques and campuses in the country. Particularly, when PAS was led by Yusof Rowa, it tried to develop itself into a cadre party with internal cells and an organic structure. During his muktamar speech in 1984, Rawa encouraged PAS members to form smaller cells among themselves. Rawa believed that through the practice of the tarbiyah study circle, PAS could easily intensify its missionary and propaganda activities. Rawaexplained,

Our efforts to improve communities' awareness have shown meaningful results. These efforts should be continued by intensifying the programs of religious speeches, courses, gathering usrah and structured halaqah...seeing the importance of the movement, it is clear that tarbiyah is very 
important...because the people we need (cadres) will not appear by themselves without training and education that are well planned and implemented with intensity (Rawa, 2000, p. 73).

This new style of membership recruitment and caderization to form smaller cells within the party seems to be identical to what PKS (Partai Keadilan Sejahtera) did in Indonesia. While PKS had started its recruitment of cadres through this method many years before it became a political party, PAS on the other hand promoted this method thirty years after its establishment. PAS gave the name usrah to its recruitment meetings, while PKS used the word liqo for its weekly meetings to recruit new cadres. However, it is very clear that the recruitment methods proposed by Rowa were influenced by the method used by Al-Al-ikhwan al-muslimun movement in Egypt. This usrah meeting was intended to bring PAS members together and encourage them to understand, develop, and propagate the ideology of the party. Noor explained that PAS divides the usrah meetings into two different types of sessions: one usrah meeting especially for the leaders of the party and other usrah for ordinary members. Noor further explained,

On some occasions, the usrah would be accompanied by kenduri (feast) held in the homes of the members themselves where non-members (non-party members) would also be invited. These meetings helped to generate a sense of belonging and fellowship (ukhwah) among the members of the Islamist party and bring them closer together (Noor, 2003, p. 6).

Noor's explanation above is correct in that the usrah gathering sometimes would be accompanied by kenduri to attract more people to come. However, it is necessary to add to Noor's point that from my experience of staying in Kota Bharu, I found that PAS expands its target of dakwah and recruitment of members into three categories: leaders and members of the party, Muslima in general and non-Muslims. PAS not only provides trainings to 
maintain the integrity of the members to the party, but also works to attract people, both Muslims and non-Muslims to become party members. As a party that holds a strong ideology and sees itself not only as a political machinery but also as an Islamic movement to spread Islamic teaching through dakwah, PAS holds the idea that it is compulsory for the party to explain to Muslims in Malaysia the comprehensiveness of Islam and the need to establish an Islamic state, called Negara Islam Kebajikan yang Diridhai (baldat toyyibat wa rabbun ghapur, a prosperious state, endorsed by God). To implement this dakwah for both Muslims and non-Muslims, the Party holds a weekly Friday gathering in front of its headquarters in Kota Bharu Kelantan in which all people can come. With regard to non-Muslims, PAS argues that those living in Kelantan could be considered as the kaffir zimmi (non-Muslims who live in harmony with Muslims and should be protected) and these groups should be allowed to become members of the party as well. PAS' treatment of the non-Muslims follows the teaching of the Prophet Muhammad who said: "whoever offends the non-Muslim or zimmi means he has offended me at the same time".

The style of recruitment like usrah initiated by Yusof Rawa has been continued by PAS leaders until the present time. In 2001, PAS published the guidelines of its membership recruitment and development, in a handbook entitled Manhaj Daurah Tadribiyah: Himpunan Kertas-kertas Kerja Pembinaan Ahli Parti Islam seMalaysia (The Methode of Training: A Collection of Papers on the Development of PAS Members). Abdul Hadi Awang (former PAS President) in his preface to this bookclearly states the purpose of its publication, saying,

I hope this book (Manhaj Daurah Tadribiyyah, The Method of Training, 2001) becomes a reference to establish a more focused standard training in the group. The commitment of all involved is expected in order to make tarbiyah a main agenda for the party in 
all levels such as the sub-district, district, provincial, and central levels as well as in all existing religious centers of today (Lajnah Tarbiyah dan Latihan Kepemimpinan PAS Pusat, 2001, p. 7).

Awang said that this book should become a formal training standard (tarbiyah guidelines) for PAS members and cadres at all levels from the lowest (cawangan) to the highest at the national level. This tarbiyah guideline is also introduced in several religious ceremonies (pengajian), which are commonly held in villages around the country particularly in Kelantan, Kedah and Terengganu, where PAS has a lot of supporters.

Usrah, taken from the Arabic which literally means "family," is the main component of PAS' tarbiyah membership training. The usrah meeting is the medium in which members of PAS can be trained together to become very loyal and integrated members through the spirit of Islamic brotherhood (ukhuwah islamiyyah). Here, the members are trained and indoctrinated in the comprehensive teachings of Islam including the idea of Islam as a very complete way of life (syamil wa mutakamil). Usrah insists upon its members to understand the comprehensive platform of PAS as an Islamic party. Thus, usrah is intended to mold PAS cadres not only as mufakkirin (cadre who is ready to think), but also amilin (cadre who is ready to act and struggle). According to tarbiyah's book of guidelines, Usrah has several specific characteristics, which are,

"1) Usrah should have continuous training, 2) cover all members both grassroot and elites, 3 ) have an orderly plan, 4) commitment of all actors both teachers and members and 5) have impacts, shown by members' ability to answer to what extent their understanding of Islam, concept of cooperation among the members and brotherhood and to what extent community works can be implemented"(Lajnah Tarbiyah dan Latihan Kepemimpinan PAS Pusat, 2001, pp. 45-46).

From the above characteristics, it is clear that usrah training of PAS is held regularly and all PAS members including 
political elites of the party have been actively involved in this. In the end, this has brought about very strong ties among the party's members. Tarbiyah as a medium to recruit members and promote PAS programs and activities has been run not only in the PAS offices but also in other places like pondok-pondok (Islamic boarding school), madrasah (Islamic schools), universities and mosques. These tarbiyah activities would be held more intensively prior to general elections. Besides attending tarbiyah of the party, the PAS statute provides guidelines or stages on how to become an ahli or a party member. According to the party statute article 10 (1-2) and article 11 (1-2), anybody who wants to become a member of PAS should apply for a membership to the official PAS office at district (cawangan) level. The member candidate should fill an official form issued by the central office of PAS at national level. The cawangan officer then recommends the membership application to the office of PAS at national level. When the officers at national level approved the application, they will issue the membership certificate (Pejabat Agung PAS Pusat, 2002, pp. 11-13)

PAS believes that education (tarbiyah) is the most important factor in their movement (harakah) to prepare qualified members and leaders who understand their Islamic vision and mission. They also believe that amaljama'i (voluntarily community services) is the core principle of their struggle, as Isaexplained:

The principles of amal jama'i should be robust particularly among young members as the rear guard of the leaders. Collective work is the basic and main core of our movement. The objective and aim of our community could be misleading if the members and leaders do not hold firmly the principles of collective work. Members and leaders should follow tarbiyah in order to understand and apprehend collective work (Isa, 2008, pp. 1-3).

As mentioned by Mat Isa above, to participate in this amal jama'i, Dewan Pemuda PAS (Youth PAS Council) has its own program that is targeted at Muslim children. According to the 
statute of the party, article 44 (3), members of Dewan Pemuda PAS are youths under forty years old (Pejabat Agung PAS Pusat, 2002, p. 90). This organization believes that Muslim children should be introduced to the principles of Islamic tarbiyah and harakah as early as possible. Thus, members of the party are required to send their children to pre-school institution organized by Dewan Pemuda PAS, called PASTI (Pusat Asuhan Tunas Islam, the Care Centre for Islamic Kids). PASTI institution was officially founded on April 10, 1987 during the $28^{\text {th }}$ muktamar (annual meeting) of Dewan Pemuda PAS. Before its official establishment, as early as 1980s, in collaboration with Angkatan Belia Islam Malaysia (ABIM), PAS had its pre-school institution called TASKI (Taman Asuhan Kanak-Kanak Islam, Childcare for Muslim Children). In Terengganu, TASKI was organized by Dewan Pemuda PAS Terengganu while in Kelantan, in 1988, they had the Putra Islam (Islamic Children) school.

The philosophical base of this pre-school institution is the continuity of activities and amal jama'i (communal effort) to create excellent young Muslim generations with good personality and good understanding and practice of Islamic teachings in their life. The pre-school curriculum suggests that their main target is to give basic knowledge of tarbiyah of the party. When they grow up, they are expected to be eager to become actively involved in the usrah or tarbiyah training.

The curriculum suggests that students since early age have been introduced to the style of tarbiyah Islamiyah (Islamic education), which is of course in line with the PAS' vision and mission. Five tarbiyah varieties such as tarbiyahimaniyah (faith), tarbiyahruhiyyah (soul), tarbiyahkhuluqiyyah (ethics), tarbiyahaqliyyah (intellect) and tarbiyahjasadiyyah (body) are among tarbiyah's activities that they focus on. Although it is hard to see to what extent this kind of pre-school program is effective as a medium to influence young children with the political ideology of PAS, during my visit to Kelantan, I found more than one hundred 
PASTI pre-schools. The students are mostly the children of PAS members, but the schools are also open to non-PAS members.

The significant number of PASTI institutions, teachers and students can contribute to the spread of PAS ideologies to the students since the early years of their education. This also means that not only does PAS use a traditional approach in recruiting their members as had been done in the early stage of its establishment through dakwah and face-to-face meetings, it also uses modern institutions like these preschool programs. This pre-school institution is currently spreading in almost every state in Malaysia.

Besides tarbiyah, usrah, and PASTI programs which are more focused on training and recruiting members, PAS also approaches people through direct dakwah activities. Dakwah or Islamic preaching is mainly intended for delivering Islamic teachings like Quranic interpretations, Hadith (Prophet Muhammad's speech and acts) and Islamic laws to the people. This is carried out by PAS' leading figures and members. Although dakwah is meant mainly to promote Islamic teachings, it is commonly known by Malaysians that this activity has been used by PAS to promote its political programs and platforms to the audiences. It has also been used to criticize governmental political policies. This means that tarbiyah and dakwah activities could be considered as tools not only to promote the party, but at the same time also to educate people to be aware of political issues in the country.

Take for example the dakwah activity which has been conducted in Kelantan. From my experience of staying in Kelantan during my observation visit, I saw how PAS used dakwah activity as a vehicle to develop people's political awareness. As a state that has been struggling to implement Islamic values in every aspect of human life, Kelantan has tried to turn itself into a model state for applying Islamic values in the economic, political, and social aspects of life.

In the political sphere, Kelantan state tries to turn itself into a place which provides political education for the people, a program commonly known as 'Kelantan open political university'. 
In Kelantan, the egalitarian relationship between political elites and their constituents, particularly during the Friday gathering, is very common. To facilitate political communication between the elites and their grassroots constituents, Kelantan through PAS has a routine and a unique political-religious program. Based on a direct observation during the field work (1-7 August 2017) in Kota Bharu, I saw that every Friday morning, in front of PAS headquarters in the center of Kota Baru, a large number of people consisting of the elderly, youth, and children come to this place to listen to Islamic and political speeches from PAS leaders like Nik Abdul Aziz. In this event, Nik Aziz delivers not only Islamic teachings but also comments on contemporary political issues in front of Khota Baru people. Every one can come to listen to this speech, whatever one's ethnic, religious, or political affiliation. This is not limited to PAS members or constituents only. In this event, I could see how an intensive personal relationship between members of the party and their leaders was built. This event shows how political elites of PAS directly or indirectly build a political awareness among the people because everybody can understand contemporary political developments and issues in Malaysia. The PAS' responses to issues are openly displayed to the public. This Friday gathering not only functions as a political tool to promote the political agendas of the party but also serves to attract new members through religious speeches delivered by a type of party elites commonly known as ulama (religious leaders). In this gathering, I also found that collections of speeches of Nik Aziz and other PAS leaders, compiled in Compact Disk (CD), were sold and people from outside Kelantan who visited Kota Bharu could easily buy the CD, which later can be used to promote PAS programs, activities and policies among their relatives and friends. Since the CDs are packed as pengajian (religious speeches), they become very effective tools to promote PAS' views and policies not only regarding Islamic issues but political matters as well. 
Table 1: Contents of Compact Disks Sold in the Friday gathering in Kelantan

\begin{tabular}{|c|c|c|}
\hline No. & Title of the CDs & Speakers \\
\hline 1. & $\begin{array}{l}\text { Melayu Islam, Islam Melayu (Me- } \\
\text { layu's Islam, Islam of Melayu) }\end{array}$ & Nik Abdul Aziz Nik Mat \\
\hline 2. & $\begin{array}{l}\text { Sidang Dun Terengganu } 2006 \text { (Meet- } \\
\text { ing of Local Parliament of Terengga- } \\
\text { nu 2006) }\end{array}$ & $\begin{array}{l}\text { Mutalib Embong, Harun Taib } \\
\text { and Wahid Endut }\end{array}$ \\
\hline 3. & $\begin{array}{l}\text { Ceramah Sempena penyerahan Bo- } \\
\text { rang Kemasukan Ahli UMNO keda- } \\
\text { lam PAS (Religious Speech during } \\
\text { the submission of form of UMNO } \\
\text { member converted to become PAS } \\
\text { member. }\end{array}$ & Hassan Muhammad Ali \\
\hline 4. & $\begin{array}{l}\text { Dunia Hingga Akhirat: Pemimpin } \\
\text { dan Pengikut Masing-masing Lepas } \\
\text { Diri (QS: 2: 166-169) (From the } \\
\text { World to the Hereafter: Leader and } \\
\text { Follower are responsible for them- } \\
\text { selves). }\end{array}$ & Nik Abdul Aziz Nik Mat \\
\hline 5. & $\begin{array}{l}\text { Kempen Bantuan Palestin: Satu } \\
\text { Ringgit Untuk Palestin (Campaign } \\
\text { to Help Palistine: One Ringgit for } \\
\text { Palestine) }\end{array}$ & $\begin{array}{l}\text { Nik Abdul Aziz Nik Mat and } \\
\text { Palestine Representatives }\end{array}$ \\
\hline 6. & $\begin{array}{l}\text { Apa Sebab Sertai PAS? (Why Join } \\
\text { PAS?) }\end{array}$ & $\begin{array}{l}\text { Wan Fuad (former UMNO } \\
\text { members) }\end{array}$ \\
\hline 7. & $\begin{array}{l}\text { Ceramah Muktamar PAS Ke } 52 \\
\text { (Kedah): Sengap Anwar Ibrahim } \\
\text { (Speech on PAS Annual Meeting } 52^{\text {nd }} \\
\text { (Kedah): Anwar Ibrahim's Speech }\end{array}$ & Anwar Ibrahim \\
\hline 8. & $\begin{array}{l}\text { Yahudi Tidak Iktiraf Kemenangan } \\
\text { HAMAS (Jews Do not Acknowledge } \\
\text { HAMAS's Victory) }\end{array}$ & Mohammad Sabu \\
\hline 9. & $\begin{array}{l}\text { Kritikan Panas Buat Pak Lah (Seri- } \\
\text { ous Criticism for Pak Lah) }\end{array}$ & $\begin{array}{l}\text { Nik Abdul Aziz Nik Mat and } \\
\text { Salahuddin Ayub }\end{array}$ \\
\hline 10. & $\begin{array}{c}\text { Penyerahan Borang Ahli Umno } \\
\text { Masuk PAS (The Submission of } \\
\text { Form, Umno Member Converted to } \\
\text { Become PAS Member) }\end{array}$ & $\begin{array}{c}\text { Mohd Anwar and Nik Abdul } \\
\text { Aziz Nik Mat }\end{array}$ \\
\hline
\end{tabular}

Source: Personal Collection of Researcher

As the table shows, it is clear that the Friday gathering in front of the PAS headquarters in Kota Bharu is used effectively by 
PAS political leaders not only to deliver religious speeches but also to promote PAS' political policies and responses to contemporary political issues in Malaysia and in the Muslim world, such as how PAS responds to the issue of Palestine in the Middle East conflict.

In this Friday gathering, information about the ruling government's policies and criticisms from PAS as an opposition party are provided to the public. Here, the people can know what the policies of the ruling government are and what the responses from PAS as an opposition party are. In this forum, Kelantan people of whatever religion, ethnic and political affiliations are indirectly educated to have an open mind in political choices. They will know the federal government's policies on certain issues and also understand how the opposition responds to such issues. Thus, the people of Kelantan are provided with political alternatives and choices of political policies for their benefit. Since this forum is organized by PAS, it is unavoidable that the forum will dominantly reflect PAS' views.

Besides the forum above, in Kelantan I also found political religious gatherings held in an open field almost every night, from one place to another interchangeably. In this gathering, huge crowds of Kelantan people usually listen to at least two or three speakers. The first speaker usually delivers a talk on religious matters such as Quran and Hadith studies and this is followed by other speakers who discuss contemporary political issues both at the local and federal government levels and even on international Islamic issues such as Palestine.

The above events are very unique. Commonly, political speeches or gatherings are held during campaign periods, but this is not the case in Kelantan. According to PAS political leaders that I met in PAS office in Kelantan, the religious and political gatherings are very important for the party. Because PAS does not have sufficient electronic or mass media resources to promote their programs and political policies, this gathering could function as the 
arena for political education of the people in the country. Although PAS has a newspaper, Harokah, as a medium to promote its political activities, it is believed that the newspaper has not adequately covered political issues in Malaysia because it is only allowed to be published fortnightly by the federal government. The experience of PAS political communication could be seen as a model on how a party communicates with its constituents. Political information, programs and policies need to be known by the constituents and the party's supporters, not only during campaign periods prior to the election time, but also after elections. Programs, policies and activities of a party should be consistently and comprehensively known by the people in order to help people easily choose the party that accommodates their political preferences. Moreover, because of the advancements of modern information technology, particularly the internet, PAS uses the online media as a tool to promote the party, including its programs, policies and activities

From the above explanation, it is clear that the party has intensively approached its constituents in particular and Kelantan people in general to get to know PAS. PAS, through its activities, not only delivers Islamic teaching or dakwah to recruit members, but also at the same time provides political awareness to constituents and people in general, at least in the case of Kelantan. This style of recruitment and dakwah activities is not specific to Kelantan, although this is its main political base in Malaysia. It can also be observed in other states like Kedah and Terengganu. By providing political education to the people, PAS has indirectly spread and promoted democratic rules to the people.

\section{PAS leadership}

A better way to know how PAS is committed to democracy is to understandhow the party implements democratic rules in its internal functions particularly in selecting its leaders. Since its early establishment until today, PAS has been committing to 
implementing democratic rules in the selection of its leaders. The PAS' commitment to holding muktamar (party annual meeting) both at national and district (cawangan) levels indicates how democratic procedures have been implemented internally. A PAS' official document states, all Jawatan Kuasa Kerja (working committee members) at the national level consist of 35 people that are elected through muktamar. Candidacies are easily put on, only requiring aspirants to obtain two nominations from PAS's branches around the country. This means that PAS gives an equal opportunity for members to be nominated as national working committee members, such as becoming the president or vice president of the party. Article 22 (1) of the PAS or party statute states,

The working committee of PAS at the national level consists of (a) a president, (b) a vice president, (c) three deputy presidents, (d) three heads of the wing organizations, (e) a secretary, (f) a treasurer, (g) a speaker of the party, and (h) twenty-four ordinary members"(Pejabat Agung PAS Pusat, 2002, p. 29).

The national muktamar as the arena to elect the party's top leaders has been designed to accommodate as many members as possible to participate in the process of election. The statute of the party article 16 (2) further states,

The annual muktamar consist of members as follows: (a) working committees and their deputies, (b) members of Majlis shura ulamak, (c) working committees from all branches at state levels, (d) head of PAS from all branches at district levels, (e) minimum four and maximum ten representatives from all branches at subsdistrict level, (f) fifteen representatives from Dewan Ulama, (g) fifteen representatives from Dewan Pemuda, and (h) fifteen representatives from Dewan Muslimat"(Pejabat Agung PAS Pusat, 2002, p. 19).

Prior to the national muktamar, many branches and divisions in the country hold their election each year to elect not 
only their working committee members at cawangan level but also their delegate for the party's annual muktamar at the national level. At least four and a maximum ten representatives from every level of branches of the party around the country are given the opportunity to vote in the national muktamar. This suggests that democratic procedures for selecting party leaders have been implemented both at the national and local levels, allowing all party members to have an equal opportunity to be a leader of the party.

Moreover, leaders of the party's wings like Dewan Pemuda, Dewan Muslimat and Dewan Ulama are elected through muktamar, which are also held every year. This also suggests that the party has several muktamar which in turn give more opportunities for the members to participate in the democratic election of its leaders. The party's statute further says,

The muktamar of Dewan Ulama PAS at national level (Article 38), Dewan Pemuda PAS at national level (article 44), and Dewan Muslimat PAS at national level (article 57) should be held once a year on the month of April or anytime as long as it is held earlier than annual muktamar of PAS central office or whenever it is needed that is decided by the working committees of each Dewan (Pejabat Agung PAS Pusat, 2002, p. 72).

Besides being used for electing the working committee of the party, the annual muktamar is also used as an arena to strengthen relationships between members and the elites of the party through face-to-face meetings. As discussed above, one of the recruitment styles of the PAS members is direct interaction between ulama and their ummah (followers), with the former being the main generators of party recruitment. The audiences come to the muktamar not only for following the party's official meetings (such as the election of the president), but also for knowing the response of the ulama as religious scholars to contemporary Islamic issues in the country. The ulamas' responses, thus, reflect the party's responses as well. 
Since the president of PAS is the ex-officio member of Majlis Syura Ulamak, the President's speech in the opening ceremony of every muktamar would become one of the most closely-watched speeches. This speech would be considered by the audiences not only as that of the PAS president but that which represents the ulama's, and therefore the party's opinion on contemporary issues. The importance of the speech, popularly known as Ucapan Dasar Muktamar (Foundation Speech of Muktamar), could be seen from the fact that during muktamar, there are several meetings held to discuss the contents of this speech. For example, during the Muktamar $52^{\text {nd }}$ in Kedah, I found that during two-day muktamar, several meetings were focused on a discussion of the president's speech, such as Usul terima kasih dan Perbahasan Ucapan Dasar Presiden (Appreciation Proposal and discussion of President's Foundation Speech), Menyambung perbahasan Ucapan Dasar Presiden (Continued Discussion of President's Foundation Speech), Perbahasan Usul-Usul and Pimpinan menjawab dan menggulung perbahasan (Discussion of the Proposals and President's Answers and Conclusion). The importance of these speeches, for example, could be seen from the enthusiasm of PAS' members in asking the party to publish the collection of the Ucapan Dasar Muktamar of the former PAS president, Fadzhil Mohd Noor, when he passed away on June 23, 2002. The book edited by Nasir Ahmad was finally published in 2003 entitled Koleksi Ucapan Dasar Muktamar PAS Kali Ke 36 Hingga 48 Selama 13 Tahun. It consists of thirteen of Noor's speeches during his thirteen years as PAS president. Nasir Ahmad, the editor of the book, writes,

His speeches are filled with the ideas that generated thoughts in solving problems related to issues such as educational, economic and social problems. They speeches also consist of his views on international issues, during his interactions with overseas leaders, particularly in regard to the Muslim's oppression all over the world (Ahmad, 2003, p. iii). 
The above discussion shows the position of the working committee members, led by the president of PAS elected in the muktamar, to be the most important in PAS. However, starting from Yosof Rowa's leadership (1983-1989), the ulama's faction obtained a stronger position in the party. This can be seen from the fact that under Rowa's leadership, the party introduced the Majlis Shura Ulamak (Consultative Council of Ulama), which has very significant power and authority in the party. This new organizational body, according to the party constitution, has the right to interpret the party's policies, to officially swear in members of the PAS working committee at the national level, and to conduct background checks of party candidates. The party statute article 7 (3) states several functions of Majlis Shura Ulamak as follows,

(a) To elaborate, explain and interpret PAS constitutions should incomprehensible articles be found in this constitution, which lead to misunderstanding of its objective, and they can make a decision on it.

(b) To give guidance and instruction in order that this constitution is followed and implemented by any person or institution involved in PAS and to keep watching and maintaining in order that the administration activities and movements of PAS follow this constitution.

(c) To maintain, defend and guard PAS's guidelines and to officially appoint members of working committee of the party (Pejabat Agung PAS Pusat, 2002, p. 5).

The party statute also states that this ulamak institution in the party should consist of fifteen members and be led by a spiritual leader known as a Mursyidul 'Am and one deputy known as Timbalan Mursyidul 'Am, who are selected through a musyawarah meeting among the Majlis Shura Ulamak members. From the fifteen Majlis 
Shura Ulamak members, four of them are appointed by the Central Committee and the Dewan Ulama respectively, who then select the remaining seven members. Due to its central position in the party, the constitution of the party demands rigorous requirements for the party's members to be elected as Majlis Shura Ulamak as the article 7 (4a) of the party statute states,

A person who will be officially elected as a member of Majlis Shura Ulamak should be someone who knows main tenets of Islam and sharia Islamic laws and understands how Islamic laws should refer to the Quran, the Hadith of the Prophet, the Ulama's agreement (ijmak) and analogical reasoning (qiyas) if some problems on Islamic matters occur. The person should also be adil (a just individual) who has never done big sins or does not practice wrong deeds continuously and he/she should protect his/her dignity and should be a member of PAS (Pejabat Agung PAS Pusat, 2002, p. 6).

Although the Majlis Shura Ulamak seems to have a very strong position even when compared to the position of the president of the party as discussed above, it is important to note that the eminence of the Majlis should not be exaggerated because with its membership drawn equally from the Central Working Committee ( 4 persons) and Dewan Ulama (4 persons), the elected members may prevail in the body's consensual dealings. The discussion above also shows that PAS has followed democratic procedures in selecting its leaders and at the same time inserted Islamic values during the process as can be seen from the requirements that PAS members should have to be elected as Majlis Shura Ulamak members.

In addition, the success of PAS's recruitment process of both members and leaders could help to institutionalize democratic values in the party. Based on the theory of party institutionalization and organization, Kikue Hamayotso divides political parties into two categories: well-institutionalized and clientelistic party (Hamayotso, 2013, p. 120). Taking into account Hamayotso's 
argument, PAS could be regarded as a well-institutionalized party. This argument is supported by the fact that the relationship between PAS's members and political elites are bound by institutionalized rules and regulations of the party. This could pave the way to the cohesion of the party and the competitiveness of all the party's members to achieve its political highest position. Finally, the good relationship among the party members and leaders, as can be seen from the case of PAS, could help the party be better institutionalized in the long run.

\section{E. Conclusion}

From the above discussion, it is very clear that PAS has practiced democratic rules in their internal party affairs. The style of PAS' recruitment of members and leaders show that the party has tried its best to implement democratic processes. The core of the training programs of usrah is to create a very loyal and integrated membership with Islamic values as a basic ideology. It is also clear that training programs held by PAS are influenced by the style of Al-ikhwan al-muslimun's Hasan Al-Bana in Egypt. The existence of Majlis Shura Ulamak also suggests that the PAS' structure is similar to that of other Islamic parties, such as PKS in Indonesia. However, different from their counterparts, such as PKS in Indonesia, PAS does not rely on polygamy, and the resultant larger families, as a tool to enlarge membership. None of PAS political elites that I met practiced polygamy, unlike PKS leaders in Indonesia. From the discussion above, it is also found that PAS mainly depends on the ulama's efforts in recruiting members.However, PAS has utilized modern instruments like the internet to promote their activities and recruit members.

In addition, PAS has its own style of promoting its ideology and programs in Kelantan through open dakwah activities in the centre of Kota Bharu, which is held weekly to educate people and promote policies. Possibly, this cannot be imitated by other Islamic 
parties like PKS in Indonesia. This is because Malaysia is a federal state in which an opposition party like PAS can become a ruling party in any state in Malaysia, such as Kelantan.

\section{REFERENCES}

Adam, R. (2000). Burhanuddin Al-Helmy: Satu Kemelut Politik. Kuala Lumpur: Dewan Bahasa dan Pustaka.

Ahmad, N. (2003). Koleksi Ucapan Dasar Muktamar PAS Kali ke 36 Hingga 48 Selama 13 Tahun. Johor: PAS Kawasan Ledangi.

Awang, A. H. (2007a). Islam \& Demokrasi. Selangor Darul Ehsan: PTS Publications \& Distributors.

Awang, A. H. (2007b). Selamatkan Demokrasi, Tegakkan Keadilan. $A$ 53rd Muktamar PAS, 1-2. Kelantan.

Case, William F. and Tong, L. C. (2006). How committed is PAS to democracy and how Do we know it? Contemporary Southeast Asia, 28(3), 385-406.

Farouk, A. F. A. (2011). The limits of civil society in democratising the state: The Malaysian case. Jurnal Kajian Malaysia, 29(1), 91-109.

Hamayotso, K. (2013). Bringing clientelism and institutions back in: The rise and fall of religious parties in Indonesia's electoral democracy. In A. D. Tomsa and Ufen (Ed.), Party Politics in Southeast Asia: Clientelism and Electoral Competition in Indonesia, Thailand and the Philippines (p. 120). New York: Routledge.

Haron, A. B. (2005). Pendirian Tuan Guru Nik Abdul Aziz Nik Mat. Kota Bharu: Dian Darulnaim Sdn. Bhd. 
Hasyim, I. (1993). PAS Kuasai Malaysia?: Sejarah Kebangkitan dan Masa Depan. Selangor Darul Ehsan: GG Edar.

Ibrahim, S. (1981). The Islamic Party of Malaysia: Its Formative Stage and Ideology. Kelantan: Nuawi bin Ismail Publication.

Isa, N. M. (2008). Pemerkasaan Wasilah Tarbiyah. Perasmian Muktamar Dewan Pemuda PAS, Ipoh, November 11, 1-3. Ipoh.

Kassim, Y. R. (2017). Najib's U-turn Over Hudud Bill: Election Gambit or Fight for Survival? RSIS Commentary No. 062, April, Singapore: Rajaratnam School of International Studies, NTU, (062), 2.

Lajnah Tarbiyah dan Latihan Kepemimpinan PAS Pusat. Manhaj Daurah Tadribiyah: Himpunan Kertas-Kertas Kerja Pembinaan Ahli Parti Islam SeMalaysia (PAS). , (2001).

Loh, F. (2012). Elections and democracy in Malaysia. The Malaysian Journal on Human Rights, 6, 21.

Moniruzzaman, M. and Farzana, K. F. (2018). Malaysia' 14th general election: End of an epoch, and beginning of a new? Intellectual Discourse Journal, 26(1), 217-228.

Muhammad, A. (1994). PAS' Platform: Development and Change, 1951-1986No Title. Selangor Darul Ehsan: Gateway Pub. House.

Noor, F. A. (2002). PAS Post-Fadzil Noor: Future Directions and Prospects. Singapore: Institute of South East Asian Studies.

Noor, F. A. (2003). Blood, sweat and jihad: The radicalization of the political discourse of the Pan-Malaysian Islamic Party (PAS) 
from 1982 onwards. Contemporary Southeast Asia, 25(2), 6.

Noor, F. A. (2015). The passing of Nik Aziz Nik Mat: Legacy of PAS' spiritual leader. RSIS Commentary, 031, 1-2.

Nor, Riduan Mohd and Ahmad, M. (2013). The Malay Muslim Dilemma in Malaysia after the 12th General Election. Malaysian Journal of Democracy and Election Studies, 1(1), 10-23. Retrieved from http://eprints.um.edu. my/10019/1/Roslan12GE.pdf

Nor, R. M. (2004). Pengaruh Pemikiran Ikhwanul Muslimin Terhadap Partai Islam se-Malaysia. Kuala Lumpur: not mentioned.

Pejabat Agung PAS Pusat. Perlembagaan Parti Islam Se Malaysia Pindaan 2001. , (2002).

Rawa, Y. (2000). Ucapan Dasar Muktamar Tahunan April 13, 1984, Alor Setar Kedah. In J. Kamaruddin (Ed.), Memperingati Yusof Rawa (p. 73). Kuala Lumpur: IKDAS Sdn., Bhd.

Saat, N. (2018). PAS' Fate in Kelantan in 2018: A Repeat of 1978 ? No Title. Perspective, 12, 1-9.

Weiss, M. L. (2013). Coalitions and competition in Malaysia: Incremental Transformation of a Strong-party System. Journal of Current Southeast Asian Affairs, 32(2), 19-37.

Zain, M. I. M. (2005). Islam dan Demokrasi: Cabaran Politik Muslim Kontemporari Malaysia. Kuala Lumpur: Penerbit Universiti Malaya.

Zain, M. I. M. (2014). From Islamist to Muslim Democrat: The Present Phenomenon of Muslim Politics in Malaysiale. International Journal of Islamic Thought, 6, 37-45. 